\title{
A multicenter study of hemodialysis using individualized dialysate potassium concentrations
}

\author{
Haidong $\mathrm{He}^{1 \#}$, Jiajun $\mathrm{Wu}^{1 \#}$, Wei $\mathrm{Lu}^{2}$, Haiyang $\mathrm{Wu}^{3}$, Rong $\mathrm{Zhu}^{4}$, Gang Yu${ }^{5}$, Gengru Jiang ${ }^{2}$, Niansong Wang ${ }^{5}$, \\ Zhiyong Guo ${ }^{3}$, Yueyi Deng ${ }^{4}$, Xudong $\mathrm{Xu}^{1}$
}

${ }^{1}$ Division of Nephrology, Fudan University, Minhang Hospital, Shanghai, China; ${ }^{2}$ Renal Division, Department of Internal Medicine, Xinhua Hospital Affiliated to Shanghai Jiao Tong University School of Medicine, Shanghai, China; ${ }^{3}$ Division of Nephrology, First Affiliated Hospital of Naval Medical University, Shanghai, China; ${ }^{4}$ Division of Nephrology, Longhua Hospital Affiliated to Shanghai University of traditional Chinese Medicine, Shanghai, China; ${ }^{5}$ Division of Nephrology, Sixth People's Hospital Affiliated to Shanghai Jiao Tong University School of Medicine, Shanghai, China

Contributions: (I) Conception and design: H He; (II) Administrative support: G Jiang, N Wang, Z Guo, Y Deng, X Xu; (III) Provision of study materials or patients: J Wu, W Lu, H Wu, R Zhu, G Yu; (IV) Collection and assembly of data: J Wu, W Lu, H Wu, R Zhu, G Yu; (V) Data analysis and interpretation: H He, J Wu; (VI) Manuscript writing: All authors; (VII) Final approval of manuscript: All authors.

\#These authors contributed equally to this work and are co-first authors.

Correspondence to: Xudong Xu. Division of Nephrology, Fudan University, Minhang Hospital, No. 170 Xinsong Road, Shanghai 201199, China. Email: xxdmzx@sina.com; Gengru Jiang. Renal Division, Department of Internal Medicine, Xinhua Hospital Affiliated to Shanghai Jiao Tong University School of Medicine, Shanghai 200092, China. Email: jianggengru@xinhuamed.com.cn.

Backgroundk Dialysate potassium concentration directly affects the serum potassium level and safety of hemodialysis patients. In most dialysis centers in China, a single dialysate potassium concentration is used for dialysis, but there is no data on whether this is reasonable or not.

Methods: Serum potassium values before and after dialysis in maintenance hemodialysis (MHD) patients between 2019 and 2020 were collected from 5 hemodialysis centers in Shanghai, which uniformly use dialysate with a potassium concentration $\left(\mathrm{K}_{\mathrm{D}}\right)$ of $2.0 \mathrm{mmol} / \mathrm{L}$, and data were collected 3 times per patient for analysis. Serum potassium fluctuation was analyzed after administration of individualized $\mathrm{K}_{\mathrm{D}}$ dialysate.

Results: In all, 1,296 MHD patients were included in the study. Predialysis serum potassium was lower than $4.5 \mathrm{mmol} / \mathrm{L}$ in $38.0 \%$ and higher than $5.5 \mathrm{mmol} / \mathrm{L}$ in $14.6 \%$ of patients. Postdialysis serum potassium was lower than $3 \mathrm{mmol} / \mathrm{L}$ in $11.3 \%$ and higher than $4 \mathrm{mmol} / \mathrm{L}$ in $10.4 \%$ of patients. Pre-dialysis serum potassium was below $4.5 \mathrm{mmol} / \mathrm{L}$ and post- dialysis serum potassium was below $3 \mathrm{mmol} / \mathrm{L}$ in $9.54 \%$ of patients. Compared with patients younger than 40 years, patients $>80$ years more often exhibited predialysis serum potassium below $4.5 \mathrm{mmol} / \mathrm{L}$ and Postdialysis serum potassium below $3 \mathrm{mmol} / \mathrm{L}$. A total of 668 patients underwent a trial of hemodialysis with individualized $\mathrm{K}_{\mathrm{D}}$ dialysate. When receiving individualized $\mathrm{K}_{\mathrm{D}}$, compared with uniform $\mathrm{K}_{\mathrm{D}} 2.0 \mathrm{mmol} / \mathrm{L}$, the number of patients with postdialysis serum potassium less than $3 \mathrm{mmol} / \mathrm{L}$ significantly decreased, the following predialysis serum potassium level was not significantly different from baseline, and the proportion of patients with predialysis serum potassium less than $4.5 \mathrm{mmol} / \mathrm{L}$ and postdialysis serum potassium less than $3 \mathrm{mmol} / \mathrm{L}$ significantly decreased.

Conclusions: Hypokalemia and fluctuations of serum potassium are common in MHD patients. $\mathrm{K}_{\mathrm{D}}$ $2.0 \mathrm{mmol} / \mathrm{L}$ dialysate should not be used for all patients, and individualized $\mathrm{K}_{\mathrm{D}}$ dialysate for patients with low serum potassium reduces the incidence of hypokalemia.

Keywords: Hemodialysis; dialysate potassium concentration; serum potassium

Submitted Sep 24, 2021. Accepted for publication Nov 09, 2021.

doi: 10.21037/apm-21-3030

View this article at: https://dx.doi.org/10.21037/apm-21-3030 


\section{Introduction}

Cardiovascular events pose the greatest risk of mortality in patients with maintenance hemodialysis (MHD), whereby sudden death is a common event (1-5). Hyperkalemia increases the risk of death in MHD patients (6-8). The factors affecting serum potassium concentration in MHD patients include potassium concentration of dialysate, residual renal function, dialysis adequacy, drugs, diet and so on. Hemodialysis can rapidly correct hyperkalemia in uremic patients, but the rapid transfer of potassium ions in a short time, resulting in rapid changes of serum potassium, is in turn an important trigger of arrhythmias and sudden death (9-13). There is an increased focus on hyperkalemia, but it is easy to ignore hypokalemia, especially postdialysis hypokalemia. Hypokalemia after dialysis increases the occurrence of ventricular arrhythmias and increases the risk of death (14-16). Dialysate potassium concentration $\left(\mathrm{K}_{\mathrm{D}}\right)$ directly affects serum potassium level in patients (17-20). Dialysate with a low $\mathrm{K}_{\mathrm{D}}$ is often administered for the purpose of correcting hyperkalemia in uremic patients. Due to traditional experience, single dialysate products, little attention to the changes of pre- and postdialysis serum potassium and no exact guidelines of dialysate potassium concentration, etc. Dialysis centers tend to uniformly use $\mathrm{K}_{\mathrm{D}} 2.0 \mathrm{mmol} / \mathrm{L}$ dialysate. The DOPPS study also showed that uniform $\mathrm{K}_{\mathrm{D}} 2.0 \mathrm{mmol} / \mathrm{L}$ dialysate was common in China (84\% of facilities). Whether $\mathrm{K}_{\mathrm{D}} 2.0 \mathrm{mmol} / \mathrm{L}$ dialysate has a general applicability is not supported by data. First, we investigated hemodialysis patients in 5 dialysis centers in Shanghai, and found that a considerable number of patients had postdialysis hypokalemia. These patients may have symptoms of discomfort during or between dialysis and be ignored for other reasons. Secondly, we looked up many studies on individualized dialysis which did not clearly propose how to individualize. Our experiment was based on a large number of studies, and patients were divided into 9 groups for individualized dialysate potassium concentration according to blood potassium before and after dialysis. As such, the study assesses the impact of using individualized $\mathrm{K}_{\mathrm{D}}$ dialysate.

We present the following article in accordance with the STROBE reporting checklist (available at https://dx.doi. org/10.21037/apm-21-3030).

\section{Methods}

\section{Study population}

Patients treated with MHD in 5 hemodialysis centers in Shanghai from July 2019 to July 2020 were included. Inclusion criteria: dialysis for longer than 3 months. Exclusion criteria: (I) high catabolism in vivo; (II) rhabdomyolysis; (III) severe inadequate fluid intake in cachectic patients; (IV) hemolysis; (V) peritoneal dialysis combined with hemodialysis; (VI) taking potassium lowering or potassium supplementation medications; or (VII) other conditions that may affect serum potassium.

\section{Study design}

The following patient information and data were collected: age, primary disease, frequency of dialysis, and pre- and postdialysis serum potassium values at 3 different times. Blood collection requirements: for patients on 3 dialysis sessions per week, predialysis blood collection required a 1-day interval between this and the previous dialysis session; for patients on dialysis twice a week, blood sampling was scheduled after a short interval. Blood sampling was performed according to specifications.

Dialysis included hemodialysis, hemodiafiltration, hemoperfusion, hemofiltration, and excluded continuous renal replacement therapy (CRRT). Dialyzer, vascular access, and anticoagulant were not specified. All patients were dialyzed against bicarbonate.

Patients were first classified into $<4.5,4.5-5.5$ and $>5.5 \mathrm{mmol} / \mathrm{L}$ groups based on the most recent predialysis serum potassium value, and then into $<3,3-4$ and $>4 \mathrm{mmol} / \mathrm{L}$ groups based on the most recent routine periodic examination of pre-and postdialysis serum potassium values in 5 dialysis centers. Individualized $\mathrm{K}_{\mathrm{D}}$ dialysate was used separately according to grouping. Groups are shown in Figure 1.

\section{Consent and ethics approval}

The clinical trial registration number for this study is: Chinese Clinical Trial Registry ChiCTR2100048841. All procedures performed in this study involving human participants were in accordance with the Declaration of Helsinki (as revised in 2013). The study was approved by institutional ethics board of Fudan University Minhang Hospital (No.: 2020-038-01K) and informed consent was taken from all the patients.

\section{Statistical analysis}

Data analysis design: (I) The distribution of pre- and postdialysis serum potassium values were analyzed. (II) The 


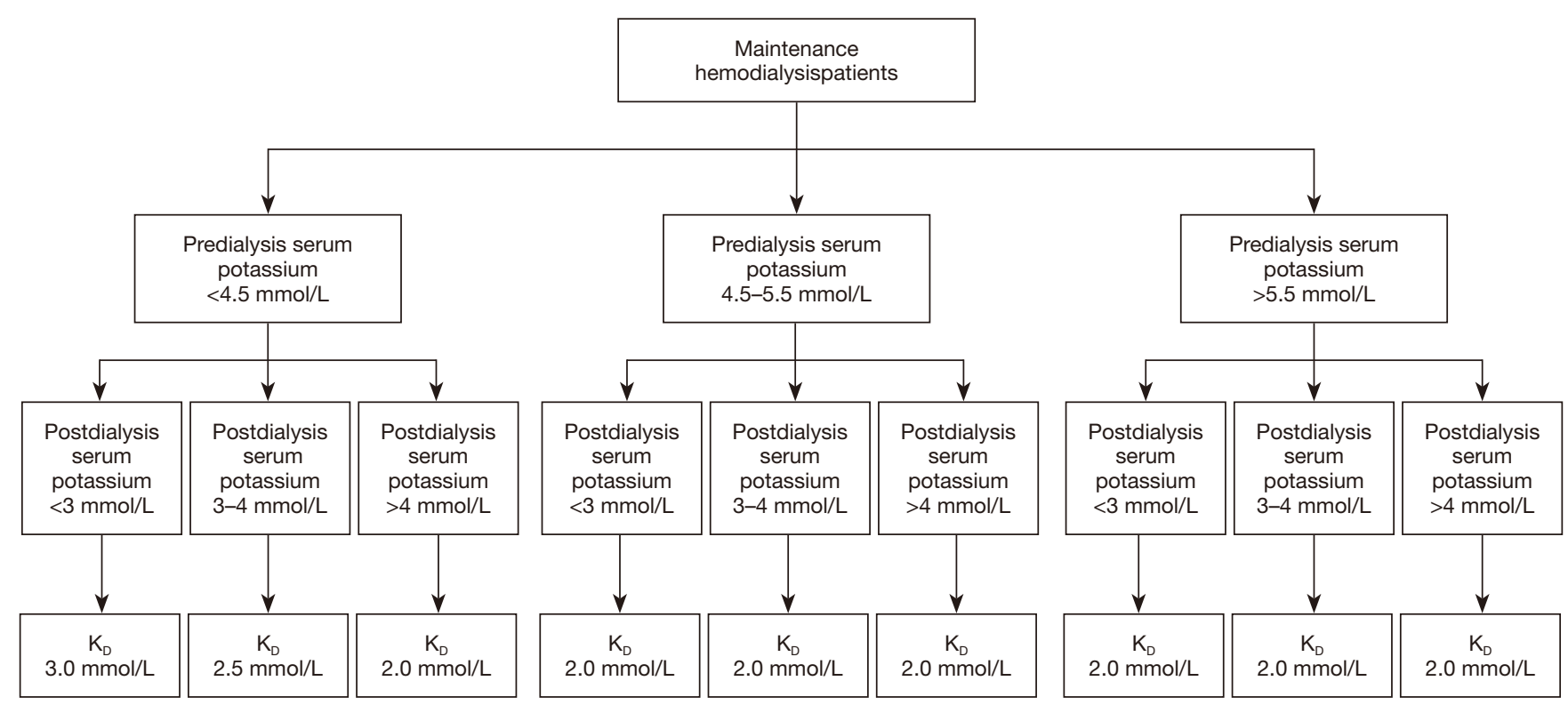

Figure 1 Individualized $\mathrm{K}_{\mathrm{D}}$ dialysate trial.

Table 1 Combination of pre- and postdialysis serum potassium

\begin{tabular}{lccc}
\hline Project & $\begin{array}{c}\text { Predialysis serum } \\
\text { potassium }<4.5 \mathrm{mmol} / \mathrm{L}\end{array}$ & $\begin{array}{c}\text { Predialysis serum } \\
\text { potassium 4.5-5.5 mmol/L }\end{array}$ & $\begin{array}{c}\text { Predialysis serum } \\
\text { potassium }>5.5 \mathrm{mmol} / \mathrm{L}\end{array}$ \\
\hline Postdialysis serum potassium $<3 \mathrm{mmol} / \mathrm{L}$ & Group 1 & Group 4 & Group 7 \\
Postdialysis serum potassium 3-4 mmol/L & Group 2 & Group 5 & Group 8 \\
Postdialysis serum potassium $>4 \mathrm{mmol} / \mathrm{L}$ & Group 3 & Group 6 & Group 9 \\
\hline
\end{tabular}

pre- and postdialysis serum potassium values were combined into 9 groups. Group 1: predialysis serum potassium values $<4.5 \mathrm{mmol} / \mathrm{L}$ and postdialysis serum potassium values $<3 \mathrm{mmol} / \mathrm{L}$; Group 2: predialysis serum potassium values $<4.5 \mathrm{mmol} / \mathrm{L}$ and postdialysis serum potassium values of 3-4 mmol/L; Group 3: predialysis serum potassium values $<4.5 \mathrm{mmol} / \mathrm{L}$ and postdialysis serum potassium values $>4 \mathrm{mmol} / \mathrm{L}$; Group 4: predialysis serum potassium values of $4.5-5.5 \mathrm{mmol} / \mathrm{L}$ and postdialysis serum potassium values $<3 \mathrm{mmol} / \mathrm{L}$; Group 5: predialysis serum potassium values of $4.5-5.5 \mathrm{mmol} / \mathrm{L}$ and postdialysis serum potassium values of 3-4 mmol/L; Group 6: predialysis serum potassium values of $4.5-5.5 \mathrm{mmol} / \mathrm{L}$ and postdialysis serum potassium values $>4 \mathrm{mmol} / \mathrm{L}$; Group 7: predialysis serum potassium values $>5.5 \mathrm{mmol} / \mathrm{L}$ and postdialysis serum potassium values $<3 \mathrm{mmol} / \mathrm{L}$; Group 8: predialysis serum potassium values $>5.5 \mathrm{mmol} / \mathrm{L}$ and postdialysis serum potassium values of
3-4 mmol/L; Group 9: predialysis serum potassium values $>5.5 \mathrm{mmol} / \mathrm{L}$, and postdialysis serum potassium values $>4 \mathrm{mmol} / \mathrm{L}$. The groups are shown in Table 1. (III) The consistency of blood potassium distributions was analyzed. (IV) Blood potassium after individualized $K_{D}$ treatment was analyzed. (V) Patients with missing data were not included in the statistical analyses.

The statistical package SPSS Version 22.0 was used to analyze the data. Numerical data are presented as means \pm standard deviations. The paired $t$-test was used for comparisons between two groups, and one-way analysis of variance (ANOVA) was used for comparisons among multiple groups; categorical data were presented as percentages, and comparisons between groups were performed using the chi square test. Scatter plots were used for correlation analysis between pre- and postdialysis potassium values, and a $\mathrm{P}$ value of $\mathrm{P}<0.05$ was considered as indicating statistical significance. 
Table 2 Predialysis serum potassium levels

\begin{tabular}{lccc}
\hline Variable & $\begin{array}{c}\text { Predialysis serum } \\
\text { potassium }<4.5 \mathrm{mmol} / \mathrm{L}\end{array}$ & $\begin{array}{c}\text { Predialysis serum } \\
\text { potassium 4.5-5.5 mmol/L }\end{array}$ & $\begin{array}{c}\text { Predialysis serum } \\
\text { potassium }>5.5 \mathrm{mmol} / \mathrm{L}\end{array}$ \\
\hline Cases (\%) & $1,479(38.0)$ & $1,843(47.4)$ & $566(14.6)$ \\
Age & $64.03 \pm 13.59$ & $62.11 \pm 12.84$ & $59.19 \pm 13.19^{\star}$ \\
\hline
\end{tabular}

*, $\mathrm{P}=0.000$ vs. predialysis serum potassium $<4.5 \mathrm{mmol} / \mathrm{L}$.

Table 3 Postdialysis serum potassium levels

\begin{tabular}{lccc}
\hline Variable & $\begin{array}{c}\text { Postdialysis serum } \\
\text { potassium }<3 \mathrm{mmol} / \mathrm{L}\end{array}$ & $\begin{array}{c}\text { Postdialysis serum } \\
\text { potassium 3-4 mmol/L }\end{array}$ & $\begin{array}{c}\text { Postdialysis serum } \\
\text { potassium }>4 \text { mmol/L }\end{array}$ \\
\hline Cases (\%) & $441(11.3)$ & $3,041(78.3)$ & $406(10.4)$ \\
Age & $67.17 \pm 11.76$ & $62.34 \pm 13.10$ & $57.62 \pm 15.22^{*}$ \\
\hline
\end{tabular}

*, $\mathrm{P}=0.000$ vs. postdialysis serum potassium $>4 \mathrm{mmol} / \mathrm{L}$.

\section{Results}

\section{Clinical characteristics of the subjects}

A total of 1,296 MHD patients were included, 831 (64.1\%) were males, and 456 (35.9\%) were females, with a mean age of $62.42 \pm 13.28$ years. The primary disease composition was as follows: chronic nephritis $(482,37.2 \%)$, diabetic nephropathy $(325,25.1 \%)$, hypertension $(163,12.6 \%)$, and other disorders (326, 25.2\%). A total of 3,888 pre- and postdialysis serum potassium values were collected.

\section{Mean serum potassium}

The mean pre- and postdialysis serum potassium values were $4.74 \pm 0.78$ and $3.45 \pm 0.49 \mathrm{mmol} / \mathrm{L}$, respectively. The difference between pre- and postdialysis serum potassium levels was $1.29 \pm 0.66 \mathrm{mmol} / \mathrm{L}$, and the difference was statistically significant $(\mathrm{r}=0.55, \mathrm{P}=0.000)$.

\section{Predialysis serum potassium}

Predialysis serum potassium values were classified into 3 groups as follows: $<4.5,4.5-5.5$, and $>5.5 \mathrm{mmol} / \mathrm{L}$. A total of 1,479 samples $(38.0 \%)$ were in the $<4.5 \mathrm{mmol} / \mathrm{L}$ group, 1,843 samples $(47.4 \%)$ in the $4.5-5.5 \mathrm{mmol} / \mathrm{L}$ group, and 566 samples $(14.6 \%)$ in the $>5.5 \mathrm{mmol} / \mathrm{L}$ group.

The mean ages of the three groups were $64.03 \pm 13.59$, $62.11 \pm 12.84$, and $59.19 \pm 13.19$ years, respectively. There was a significant difference in age between the predialysis serum potassium $<4.5 \mathrm{mmol} / \mathrm{L}$ group and the $>5.5 \mathrm{mmol} / \mathrm{L}$ group $(\mathrm{P}=0.000)$ (Table 2).

\section{Postdialysis serum potassium}

Postdialysis serum potassium was classified into three groups as follows: $<3,3-4$, and $>4 \mathrm{mmol} / \mathrm{L}$. There were 441 samples in the $<3 \mathrm{mmol} / \mathrm{L}$ group (11.34\%), 3,041 samples in the $3-4 \mathrm{mmol} / \mathrm{L}$ group $(78.22 \%)$, and 406 samples in the $>4 \mathrm{mmol} / \mathrm{L}$ group $(10.44 \%)$. The mean ages of the three groups were $67.17 \pm 11.76,62.34 \pm 13.10$, and $57.62 \pm 15.22$ years, respectively. There was a significant difference in age between the postdialysis serum potassium $<3 \mathrm{mmol} / \mathrm{L}$ group and the $>4 \mathrm{mmol} / \mathrm{L}$ group $(\mathrm{P}=0.000)$ (Table 3).

\section{Combined analysis of pre- and postdialysis serum potassium}

Pre- and postdialysis serum potassium combinations were classified into 9 groups. There were 124 samples (9.54\%) with low pre- and postdialysis serum potassium. The mean ages of the 9 groups were $66.18 \pm 12.47,63.43 \pm 13.86$, $59.95 \pm 14.27,61.04 \pm 10.77,62.21 \pm 12.63,61.55 \pm 15.09$, $64.57 \pm 9.50,59.96 \pm 12.40$, and $57.29 \pm 14.64$ years. There were significant differences in age between Group 1 and Group 3, and between Group 7 and Group 9 (P=0.001 and $\mathrm{P}=0.024$, respectively) (Table 4).

\section{Analysis of serum potassium stability}

Each patient had 3 combinations of pre- and postdialysis serum potassium values, and the consistency of the 3 combinations across the groups is shown in Table 5 .

A value of ' 0 ' in Table 5 represents cases where values 
Table 4 Pre- and postdialysis serum potassium combinations

\begin{tabular}{lccccccccc}
\hline Variable & Group 1 & Group 2 & Group 3 & Group 4 & Group 5 & Group 6 & Group 7 & Group 8 & Group 9 \\
\hline Cases (\%) & $124(9.54)$ & $357(27.52)$ & $13(0.98)$ & $19(1.44)$ & $652(50.30)$ & $60(4.66)$ & $4(0.36)$ & $5(0.39)$ & $62(4.81)$ \\
Age & $66.18 \pm 12.47$ & $63.43 \pm 13.86$ & $59.95 \pm 14.27^{*}$ & $61.04 \pm 10.77$ & $62.21 \pm 12.63$ & $61.55 \pm 15.09$ & $64.57 \pm 9.50$ & $59.96 \pm 12.40$ & $57.29 \pm 14.64^{\&}$ \\
\hline
\end{tabular}

*, $\mathrm{P}=0.001$ vs. Group $1 ;{ }^{\circledR}, \mathrm{P}=0.024$ vs. Group 7.

Table 5 Analysis of blood potassium fluctuation

\begin{tabular}{lccr}
\hline Variable & 0 & 2 & 3 \\
\hline Cases (\%) & $238(18.4)$ & $733(56.6)$ & $325(25.0)$ \\
Age & $61.08 \pm 13.64$ & $62.84 \pm 13.09$ & $62.44 \pm 13.41$ \\
\hline
\end{tabular}

Table 6 Serum potassium levels with different dialysis frequency

\begin{tabular}{|c|c|c|c|c|}
\hline Variable & Twice a week & 3 times a week & $\mathrm{T}$ & $\mathrm{P}$ \\
\hline Predialysis 2 & $4.54 \pm 0.83$ & $4.72 \pm 0.76$ & -2.08 & 0.038 \\
\hline Predialysis 3 & $4.56 \pm 0.78$ & $4.74 \pm 0.76$ & -2.14 & 0.033 \\
\hline Predialysis mean & $4.51 \pm 0.71$ & $4.76 \pm 0.66$ & -3.29 & 0.001 \\
\hline Postdialysis 2 & $3.37 \pm 0.49$ & $3.43 \pm 0.46$ & -1.13 & 0.257 \\
\hline Postdialysis 3 & $3.35 \pm 0.53$ & $3.52 \pm 0.55$ & -2.88 & 0.004 \\
\hline Predialysis mean & $3.35 \pm 0.36$ & $3.47 \pm 0.36$ & -2.98 & 0.003 \\
\hline
\end{tabular}

were in different groups 3 times; '2' represents cases where values were in the same group 2 out of 3 times; and ' 3 ' represents where values were in the same group 3 times. There were $238(18.36 \%)$ cases in the ' 0 '-times group, 733 $(56.56 \%)$ in the ' 2 '-times group, and $325(25.10 \%)$ times in the ' 3 '-times group. The ages of patients in the 3 groups were $61.08 \pm 13.64,62.84 \pm 13.09$, and $62.44 \pm 13.41$ years, respectively, and there was no significant difference in age among the 3 groups (Table 5).

\section{Serum potassium levels with different dialysis frequency}

Pre- and postdialysis potassium levels were higher in patients who had dialysis 3 times a week compared with those who had dialysis twice a week $(\mathrm{P}<0.05)$ (Table 6).

\section{Age and serum potassium}

The proportion of patients aged $>80$ years with predialysis serum potassium $<4.5 \mathrm{mmol} / \mathrm{L}$ was significantly higher than that of patients aged $<40$ years $(\mathrm{P}=0.002)$, and the proportion of patients aged $>80$ years with predialysis serum potassium $>5.5 \mathrm{mmol} / \mathrm{L}$ was significantly lower than that of patients aged $<40$ years $(\mathrm{P}=0.000)$. The proportion of patients aged $>80$ years with postdialysis serum potassium $<3 \mathrm{mmol} / \mathrm{L}$ was significantly higher than that of patients aged $<40$ years $(\mathrm{P}=0.000)$, and the proportion of patients aged $>80$ years with postdialysis serum potassium $>4 \mathrm{mmol} / \mathrm{L}$ was significantly lower than that of patients aged $<40$ years $(\mathrm{P}=0.000)$ (Tables 7,8).

According to the combination grouping method, the proportion of patients $>80$ years in Group 1 was significantly higher than that of patients $<40$ years $(\mathrm{P}=0.014)$, and the proportion of patients $>80$ years in Group 9 was significantly lower than that of patients aged $<40$ years $(\mathrm{P}=0.001)$ (Table 9).

According to previous stability criteria, there was no significant difference in the fluctuation of serum potassium 
Table 7 Predialysis serum potassium in different age groups

\begin{tabular}{lccc}
\hline Age & $\begin{array}{c}\text { Predialysis serum } \\
\text { potassium }<4.5 \mathrm{mmol} / \mathrm{L}\end{array}$ & $\begin{array}{c}\text { Predialysis serum } \\
\text { potassium 4.5-5.5 mmol/L }\end{array}$ & $\begin{array}{c}\text { Predialysis serum } \\
\text { potassium }>5.5 \mathrm{mmol} / \mathrm{L}\end{array}$ \\
\hline$<40, \mathrm{n}(\%)$ & $99(36.7)$ & $116(43.0)$ & $55(20.4)$ \\
$40-, \mathrm{n}(\%)$ & $373(33.2)$ & $553(49.2)$ & $199(17.7)$ \\
$60-, \mathrm{n}(\%)$ & $824(38.6)$ & $1,025(48.1)$ & $284(13.3)$ \\
$80-, \mathrm{n}(\%)$ & $183(50.8)^{\star}$ & $149(41.4)$ & $28(7.8)^{\&}$ \\
\hline
\end{tabular}

*, $\mathrm{P}=0.002$ vs. age $<40 ;{ }^{\&}, \mathrm{P}=0.000$ vs. age $<40$.

Table 8 Postdialysis serum potassium in different age groups

\begin{tabular}{lccc}
\hline Age & $\begin{array}{c}\text { Postdialysis serum } \\
\text { potassium }<3 \mathrm{mmol} / \mathrm{L}\end{array}$ & $\begin{array}{c}\text { Postdialysis serum } \\
\text { potassium 3-4 mmol/L }\end{array}$ & $\begin{array}{c}\text { Postdialysis serum } \\
\text { potassium }>4 \mathrm{mmol} / \mathrm{L}\end{array}$ \\
\hline$<40, \mathrm{n}(\%)$ & $15(5.6)$ & $206(76.3)$ & $49(18.2)$ \\
$40-$, n (\%) & $113(10.0)$ & $875(77.8)$ & $137(12.2)$ \\
$60-$, n (\%) & $263(12.3)$ & $1,686(79.0)$ & $184(8.6)$ \\
$80-$, n (\%) & $50(13.9)^{*}$ & $274(76.1)$ & $36(10.0)^{\&}$ \\
\hline
\end{tabular}

${ }^{*}, \mathrm{P}=0.000$ vs. age $<40 ;{ }^{*}, \mathrm{P}=0.000$ vs. age $<40$.

Table 9 Pre- and postdialysis serum potassium combinations in different ages

\begin{tabular}{lccccccccc}
\hline Age & Group 1 & Group 2 & Group 3 & Group 4 & Group 5 & Group 6 & Group 7 & Group 8 & Group 9 \\
\hline$<40, \mathrm{n}(\%)$ & $13(13.1)$ & $81(81.8)$ & $5(5.1)$ & $2(1.7)$ & $95(81.9)$ & $19(16.4)$ & $0(0.0)$ & $30(54.6)$ & $25(45.5)$ \\
$40-$, n (\%) & $88(23.6)$ & $274(72.5)$ & $11(3.0)$ & $23(4.2)$ & $475(85.9)$ & $55(10.0)$ & $2(1.0)$ & $126(63.3)$ & $71(35.7)$ \\
$60-$, n (\%) & $223(27.1)$ & $582(70.6)$ & $19(2.3)$ & $29(2.8)$ & $911(88.9)$ & $85(8.3)$ & $11(3.9)$ & $193(68.0)$ & $80(28.2)$ \\
$80-$, n (\%) & $47(25.7)^{\star}$ & $133(72.7)$ & $3(1.6)$ & $2(1.3)$ & $125(83.9)$ & $22(14.8)$ & $1(3.6)$ & $16(57.1)$ & $11(39.3)^{\&}$ \\
\hline
\end{tabular}

*, $\mathrm{P}=0.014$ vs. age $<40 ;{ }^{\&}, \mathrm{P}=0.001$ vs. age $<40$.

Table 10 Analysis of blood potassium fluctuation in different age groups

\begin{tabular}{lccc}
\hline Age & 0 & 2 & 3 \\
\hline$<40$, n (\%) & $19(21.1)$ & $47(52.2)$ & $24(26.7)$ \\
$40-$, n (\%) & $81(21.6)$ & $208(55.5)$ & $86(22.9)$ \\
$60-$, n (\%) & $115(16.2)$ & $409(57.5)$ & $187(26.3)$ \\
$80-$, n (\%) & $23(19.2)$ & $69(57.5)$ & $28(23.3)$ \\
\hline
\end{tabular}

between different ages $(\mathrm{P}>0.05)$ (Table 10).

\section{Primary disease and serum potassium}

All patients were classified into 4 groups according to whether they had hypertensive nephropathy, diabetic nephropathy, chronic nephritis, or other diseases. There was no significant difference in predialysis serum potassium between patients with different primary diseases. The proportion of patients with postdialysis serum potassium $<3 \mathrm{mmol} / \mathrm{L}$ was significantly higher in the group with other diseases than those with diabetic nephropathy and 
Table 11 Predialysis serum potassium in different primary diseases

\begin{tabular}{lccr}
\hline Primary disease & $\begin{array}{c}\text { Predialysis serum } \\
\text { potassium }<4.5 \mathrm{mmol} / \mathrm{L}\end{array}$ & $\begin{array}{c}\text { Predialysis serum } \\
\text { potassium 4.5-5.5 mmol/L }\end{array}$ & $\begin{array}{c}\text { Predialysis serum } \\
\text { potassium }>5.5 \mathrm{mmol} / \mathrm{L}\end{array}$ \\
\hline Hypertensive nephropathy, $\mathrm{n}(\%)$ & $205(41.9)$ & $224(45.8)$ & $60(12.3)$ \\
Diabetic nephropathy, $\mathrm{n}(\%)$ & $354(36.3)$ & $469(48.1)$ & $152(15.6)$ \\
Chronic nephritis, $\mathrm{n}(\%)$ & $530(36.7)$ & $705(48.8)$ & $211(14.6)$ \\
Other diseases, $\mathrm{n}(\%)$ & $390(39.9)$ & $445(45.5)$ & $143(14.6)$ \\
\hline
\end{tabular}

Table 12 Postdialysis serum potassium in different primary diseases

\begin{tabular}{lccc}
\hline Primary disease & $\begin{array}{c}\text { Postdialysis serum } \\
\text { potassium }<3 \mathrm{mmol} / \mathrm{L}\end{array}$ & $\begin{array}{c}\text { Postdialysis serum } \\
\text { potassium 3-4 mmol/L }\end{array}$ & $\begin{array}{c}\text { Postdialysis serum } \\
\text { potassium }>4 \text { mmol/L }\end{array}$ \\
\hline Hypertensive nephropathy, $\mathrm{n}(\%)$ & $60(12.3)$ & $381(77.9)$ & $48(9.8)$ \\
Diabetic nephropathy, $\mathrm{n}(\%)$ & $85(8.7)$ & $770(79.0)$ & $120(12.3)$ \\
Chronic nephritis, $\mathrm{n}(\%)$ & $156(10.8)$ & $1,146(79.3)$ & $144(10.0)$ \\
Other diseases, $\mathrm{n}(\%)$ & $140(14.3)^{\star *}$ & $744(76.1)$ & $94(9.6)$ \\
\hline
\end{tabular}

*, $\mathrm{P}=0.0002$ vs. diabetic nephropathy; ${ }^{\circledR}, \mathrm{P}=0.0339$ vs. chronic nephritis.

Table 13 Pre- and postdialysis serum potassium combinations in different primary diseases

\begin{tabular}{lccccccccc}
\hline Primary disease & Group 1 & Group 2 & Group 3 & Group 4 & Group 5 & Group 6 & Group 7 & Group 8 & Group 9 \\
\hline Hypertensive nephropathy, n (\%) & $46(22.4)$ & $155(75.6)$ & $4(2.0)$ & $11(4.9)$ & $190(84.8)$ & $23(10.3)$ & $3(5.0)$ & $36(60.0)$ & $21(35.0)$ \\
Diabetic nephropathy, n (\%) & $74(20.9)$ & $268(75.7)$ & $12(3.4)$ & $9(1.9)$ & $412(87.9)$ & $48(10.2)$ & $2(1.3)$ & $90(59.2)$ & $60(39.5)$ \\
Chronic nephritis, n (\%) & $133(25.1)$ & $382(72.1)$ & $15(2.8)$ & $18(2.6)$ & $617(87.5)$ & $70(9.9)$ & $5(2.4)$ & $147(69.7)$ & $59(28.0)$ \\
Other diseases, n (\%) & $118(30.3)$ & $265(68.0)$ & $7(1.8)$ & $18(4.0)$ & $387(87.0)$ & $40(9.0)$ & $4(2.8)$ & $92(64.3)$ & $47(32.9)$ \\
\hline
\end{tabular}

Table 14 Analysis of blood potassium fluctuation in different primary diseases

\begin{tabular}{lccc}
\hline Primary disease & 0 & 2 & 3 \\
\hline Hypertensive nephropathy, $\mathrm{n}(\%)$ & $27(16.6)$ & $93(57.1)$ & $43(26.4)$ \\
Diabetic nephropathy, $\mathrm{n}(\%)$ & $63(19.4)$ & $197(60.6)$ & $65(20.0)$ \\
Chronic nephritis, $\mathrm{n}(\%)$ & $80(16.6)$ & $269(55.8)$ & $133(27.6)$ \\
Other diseases, $\mathrm{n}(\%)$ & $68(20.7)$ & $174(53.4)$ & $84(25.8)$ \\
\hline
\end{tabular}

chronic nephritis $(\mathrm{P}=0.0002$ and $\mathrm{P}=0.0339$, respectively) (Tables 11,12).

Pre- and postdialysis serum potassium combinations were analyzed in different primary diseases. There were no significant differences in pre- and postdialysis serum potassium combinations between patients with different primary diseases (Table 13).

There were no significant differences in serum potassium fluctuation between different primary diseases (Table 14).

\section{Serum potassium after dialysis with individualized $K_{D}$ dialysate}

A total of 668 patients in the 5 dialysis centers underwent an individualized $\mathrm{K}_{\mathrm{D}}$ dialysate trial. Individualized $\mathrm{K}_{\mathrm{D}}$ dialysate dialysis was administered according to the study protocol. 
Table 15 Postdialysis serum potassium with individualized KD dialysate

\begin{tabular}{lccc}
\hline Variable & $\begin{array}{c}\text { Postdialysis serum } \\
\text { potassium }<3 \mathrm{mmol} / \mathrm{L}\end{array}$ & $\begin{array}{c}\text { Postdialysis serum } \\
\text { potassium 3-4 mmol/L }\end{array}$ & $\begin{array}{c}\text { Postdialysis serum } \\
\text { potassium }>4 \text { mmol/L }\end{array}$ \\
\hline Base line cases (\%) & $93(13.9)$ & $517(77.4)$ & $58(8.7)$ \\
Individualized K $\mathrm{D}_{\mathrm{D}}$ cases (\%) & $37(5.5)$ & $565(84.5)$ & $66(9.9)$ \\
$\chi^{2}$ & 27.5066 & 11.5031 & 0.5865 \\
$\mathrm{P}$ & 0.000 & 0.0007 & 0.4438 \\
\hline
\end{tabular}

Table 16 Next predialysis serum potassium with individualized KD dialysate

\begin{tabular}{lccc}
\hline Variable & $\begin{array}{c}\text { Predialysis serum } \\
\text { potassium }<4.5 \mathrm{mmol} / \mathrm{L}\end{array}$ & $\begin{array}{c}\text { Predialysis serum } \\
\text { potassium 4.5-5.5 mmol/L }\end{array}$ & $\begin{array}{c}\text { Predialysis serum } \\
\text { potassium }>5.5 \mathrm{mmol} / \mathrm{L}\end{array}$ \\
\hline Baseline cases (\%) & $275(41.2)$ & $295(44.2)$ & $98(14.6)$ \\
Individualized $\mathrm{K}_{\mathrm{D}}$ cases (\%) & $249(37.3)$ & $324(48.5)$ & $95(14.2)$ \\
$\chi^{2}$ & 2.1408 & 2.5537 & 0.0555 \\
$\mathrm{P}$ & 0.1434 & 0.1100 & 0.8137 \\
\hline
\end{tabular}

Table 17 Pre- and postdialysis serum potassium combinations with individualized KD dialysate

\begin{tabular}{lccccccccc}
\hline Variable & Group 1 & Group 2 & Group 3 & Group 4 & Group 5 & Group 6 & Group 7 & Group 8 & Group 9 \\
\hline Baseline cases (\%) & $82(12.3)$ & $191(28.6)$ & $1(0.2)$ & $9(1.4)$ & $274(41.0)$ & $15(2.3)$ & $0(0)$ & $56(8.4)$ & $40(6.0)$ \\
Individualized K cases (\%) & $26(3.9)$ & $208(31.1)$ & $5(0.6)$ & $8(1.2)$ & $296(44.3)$ & $20(3.0)$ & $2(0.3)$ & $62(9.3)$ & $41(6.1)$ \\
$\chi^{2}$ & 31.591 & 1.033 & 2.679 & 0.0596 & 1.481 & 0.7335 & 2.003 & 0.3346 & 0.0131 \\
$P$ & 0.000 & 0.3095 & 0.1017 & 0.0872 & 0.2236 & 0.3918 & 0.1570 & 0.5629 & 0.9087 \\
\hline
\end{tabular}

The postdialysis serum potassium profile was significantly different for patients receiving individual $\mathrm{K}_{\mathrm{D}}$ dialysates compared to those receiving the uniform $\mathrm{K}_{\mathrm{D}} 2.0 \mathrm{mmol} / \mathrm{L}$.

There was a significant reduction in patients with postdialysis serum potassium $<3 \mathrm{mmol} / \mathrm{L}(\mathrm{P}=0.000)$ and a significant increase in those with $3-4 \mathrm{mmol} / \mathrm{L}(\mathrm{P}=0.0007)$.

Serum potassium was not significantly different from baseline before the next dialysis session (Tables 15,16).

Patients in Group 1 (predialysis serum potassium $<4.5 \mathrm{mmol} / \mathrm{L}$ and postdialysis serum potassium $<3 \mathrm{mmol} / \mathrm{L}$ ) had significantly reduced $(\mathrm{P}=0.000)$ (Table 17).

\section{Discussion}

Hyperkalemia is a common complication in uremic patients and can be life-threatening. Hyperkalemia is a frequent concern among physicians and patients with blood permeability. To avoid adverse events, low potassium dialysate is often used to correct hyperkalemia, especially predialysis hyperkalemia. Pun et al. (21) compared clinical and dialysis data from 502 cardiac arrest patients and found that predialysis serum potassium of $5.1 \mathrm{mmol} / \mathrm{L}$ had the lowest incidence of cardiac arrest. Each $1 \mathrm{mmol} / \mathrm{L}$ increase was associated with a $38 \%$ increase and each $1 \mathrm{mmol} / \mathrm{L}$ decrease was associated with a $49 \%$ increase in cardiac arrest. Predialysis serum potassium has an important impact on the survival of MHD patients (22,23). Another study (24) showed that predialysis serum potassium between 4.6 and $5.3 \mathrm{mmol} / \mathrm{L}$ was associated with the highest survival rates, and that both less than 4.0 or greater than $5.6 \mathrm{mmol} / \mathrm{L}$ were associated with increased mortality rates. The above studies suggest that a predialysis serum potassium level of around $5 \mathrm{mmol} / \mathrm{L}$ is ideal. Our study showed that the average level of predialysis serum potassium in this multicenter study of MHD patients in Shanghai was $4.74 \pm 0.78 \mathrm{mmol} / \mathrm{L}$, whereby $47.4 \%$ of patients had a predialysis serum potassium control 
in the ideal range of $4.5-5.5 \mathrm{mmol} / \mathrm{L}$, and a $\mathrm{K}_{\mathrm{D}} 2.0 \mathrm{mmol} / \mathrm{L}$ dialysate was suitable for this subset of patients. Patients with predialysis serum potassium greater than $5.5 \mathrm{mmol} / \mathrm{L}$ were relatively young. In particular, $20.4 \%$ of patients younger than 40 years had a pretransfusion serum potassium greater than $5.5 \mathrm{mmol} / \mathrm{L}$, which may be associated with a varied diet and poor control in younger dialysis patients and warrants an emphasis on serum potassium management in this population. Differences in primary disease did not affect predialysis serum potassium levels in MHD patients.

The impact of postdialysis serum potassium in patients with MHD is also of concern. Japanese data from the DOPPS study (16) was used to analyze the association between postdialysis hypokalemia and all-cause mortality in 3,967 dialysis patients. MHD patients with postdialysis serum potassium less than $3.0 \mathrm{mmol} / \mathrm{L}$ had a higher risk of all-cause mortality compared to those with predialysis serum potassium $3.0-3.5 \mathrm{mmol} / \mathrm{L}$, especially if the predialysis serum potassium was less than $4.5 \mathrm{mmol} / \mathrm{L}$. This suggests that postdialysis hypokalemia management is also particularly important. Our study shows that $78.22 \%$ of patients achieved postdialysis serum potassium levels in the ideal range of 3-4 mmol/L, and a $\mathrm{K}_{\mathrm{D}} 2.0 \mathrm{mmol} / \mathrm{L}$ dialysate was also suitable for this proportion of patients. Similar to predialysis potassium levels, the proportion of postdialysis hyperkalemia was higher in patients younger than 40 years, whereas the proportion of postdialysis hypokalemia was higher in patients older than 80 years. The proportion of patients with postdialysis serum potassium levels less than $3 \mathrm{mmol} / \mathrm{L}$ was significantly higher in the other disease groups than in the diabetic nephropathy and chronic nephritis groups. Therefore, the risk of postdialysis hypokalemia is present in more than $20 \%$ of patients, especially in older adults and those with partial primary disease.

The biggest contributing factor to serum potassium levels in hemodialysis patients is the potassium concentration of the dialysate. Karaboyas et al. (25) compared $\mathrm{K}_{\mathrm{D}}$ $2.0 \mathrm{mmol} / \mathrm{L}$ with $\mathrm{K}_{\mathrm{D}} 3.0 \mathrm{mmol} / \mathrm{L}$ and found no significant differences in the effect of predialysis serum potassium concentrations. Agar et al. (17) dialyzed with 4 potassium concentrations, i.e., $0,1,2$ and $3 \mathrm{mmol} / \mathrm{L}$ dialysate, and the serum potassium value before and after dialysis was positively correlated with the dialysate potassium concentration. Dolson et al. (26) used 3 dialysate potassium concentrations of 1,2 , and $3 \mathrm{mmol} / \mathrm{L}$, and all 3 dialysate potassium concentrations decreased the postdialysis serum potassium level, whereby the dialysis serum potassium level gradually increased with the increase of dialysate potassium concentration, but there was no significant difference in the next predialysis serum potassium concentration. Our study showed that the use of a $\mathrm{K}_{\mathrm{D}} 2.0 \mathrm{mmol} / \mathrm{L}$ dialysate reduced predialysis serum potassium $1.29 \mathrm{mmol} / \mathrm{L}$ on average.

A $K_{D} 2.0 \mathrm{mmol} / \mathrm{L}$ dialysate is often used consistently in the clinic to reduce predialysis hyperkalemia. However, scholars wanted to explore the suitability of low potassium dialysate for all patients and questions whether lower levels are necessarily always better (27). A prospective cohort study (28), which administered 1,2 , and $3 \mathrm{mmol} / \mathrm{L}$ potassium dialysate, showed that the $1 \mathrm{mmol} / \mathrm{L}$ group had a higher mortality rate. A review by Jadoul (5) included 37,765 dialysis patients and showed that sudden death was higher in patients with $\mathrm{K}_{\mathrm{D}}$ less than 1.5 and with $2-2.5 \mathrm{mmol} / \mathrm{L}$ compared with $\mathrm{K}_{\mathrm{D}}$ higher than $3 \mathrm{mmol} / \mathrm{L}$, especially in patients with predialysis serum potassium less than $5 \mathrm{mmol} / \mathrm{L}$. Our study found that for $87.1 \%$ of patients with predialysis serum potassium of $4.5-5.5 \mathrm{mmol} / \mathrm{L}$ postdialysis levels of 3-4 mmol/L could be achieved, which is suggestive of a low cardiovascular and mortality risk, and indicates that a $\mathrm{K}_{\mathrm{D}}$ of $2.0 \mathrm{mmol} / \mathrm{L}$ of dialysate is suitable.

Twenty-five percent $(25.1 \%)$ of patients with predialysis serum potassium less than $4.5 \mathrm{mmol} / \mathrm{L}$ had postdialysis serum potassium less than $3 \mathrm{mmol} / \mathrm{L}$ (9.54\% of the total). According to previous studies, these patients have a considerable risk of sudden death and a high rate of hospitalization (29-31). Such low serum potassium levels are often overlooked in the clinic. A $\mathrm{K}_{\mathrm{D}} 2.0 \mathrm{mmol} / \mathrm{L}$ dialysate may be too low for such patients (32), and a higher dialysate potassium concentration would be more suitable for this patient group. For patients with predialysis serum potassium exceeding $5.5 \mathrm{mmol} / \mathrm{L}$, only $5.6 \%(0.36 \%$ of the total) presented with postdialysis serum potassium less than $3 \mathrm{mmol} / \mathrm{L}$. Most patients have a postdialysis serum potassium level higher than $3 \mathrm{mmol} / \mathrm{L}$, and such patients do not have an increased risk of mortality, and even a relatively low potassium dialysate protects against sudden cardiac death risk (33). Therefore, a $\mathrm{K}_{\mathrm{D}}$ of $2.0 \mathrm{mmol} / \mathrm{L}$ dialysate is equally suitable for this group of patients. The risk for these patients is predialysis hyperkalemia, and higher potassium removal during dialysis also does not prevent the rapid rebound of serum potassium (34), suggesting that predialysis blood control is critically linked to the interdialysis period. It is recommended that such patients receive a controlled diet and medications during the interdialysis period to reduce predialysis hyperkalemia. Therefore, we mainly used $\mathrm{K}_{\mathrm{D}} 3.0$ and $2.5 \mathrm{mmol} / \mathrm{L}$ dialysate for individual dialysis in Group 1 and Group 2, respectively. In addition, our 
study found that the mean age of patients with postdialysis hypokalemia was higher than that of the other groups $(66.18 \pm 12.4 v s .64 .57 \pm 9.50$, respectively), regardless of predialysis hyper- and hypokalemia. This suggests that older patients are more likely to experience postdialysis hypokalemia. Previous studies (35-38) showed an unclear relationship between age and serum potassium levels in patients with chronic kidney disease, and our findings fill this gap in the literature.

Previous studies focused solely on pre- or postdialysis serum potassium analysis. However, predialysis and Postdialysis serum potassium levels are not isolated. Fewer studies have combined predialysis and postdialysis serum potassium levels as an assessment of serum potassium volatility. Our study showed that for $81.6 \%$ of patients on a stable diet and stable medication at least 2 of the 3 preand postdialysis potassium combinations did not change. This means that nearly $20 \%$ of dialysis patients showed significant fluctuations in their serum potassium levels, and management of this subset of patients is also worth paying attention to. We also investigated the effect of different dialysis frequencies on serum potassium levels, showing that pre- and postdialysis serum potassium was higher $(\mathrm{P}<0.05)$ in patients dialyzed 3 times a week than those dialyzed twice a week. It was speculated that patients on dialysis twice a week might have more residual renal function and urine volume. However, it was not possible to analyze this further, because no other data addressing this question were included in this investigation.

The significance of this study is to highlight the presence of hypokalemia and fluctuations of serum potassium. The findings compensate for the lack of previous studies, where the focus was predominantly on predialysis hyperkalemia. The large amount of data collected in this multicenter study describes blood potassium fluctuations in MHD patients and provides the basis for the design of targeted clinical intervention studies. Based on extensive data analysis, we designed protocols for individualized potassium concentration dialysate treatments. The starting point of the protocol design was to see whether individualized potassium concentration dialysate therapy reduces hypokalemia and to examine the safety of this approach. The use of individualized $\mathrm{K}_{\mathrm{D}}$ dialysate not only reduces the incidence of postdialysis hypokalemia but also carries no risk of hyperkalemia. This and other studies show that this approach may result in benefits for patients.

In summary, $K_{D} 2.0 \mathrm{mmol} / \mathrm{L}$ dialysate is appropriate for most patients and is a widely accepted concentration.
However, for a small proportion of patients, especially older patients and those with hypokalemia before and after dialysis, many studies demonstrated that higher concentrations of potassium dialysate are needed for these types of patients to ameliorate postdialysis hypokalemia and achieve a reduction of the risk of death.

Therefore, it is necessary to use individualized $K_{D}$ dialysate based on daily monitored serum potassium levels. Individualized $\mathrm{K}_{\mathrm{D}}$ dialysate significantly corrects postdialysis hypokalemia and does not cause subsequent predialysis potassium levels to rise. This study shows how serum potassium fluctuations can be reduced and how postdialysis hypokalemia can be corrected in MHD patients, which in turn may be beneficial for reducing clinical cardiovascular events. Of course, this study has some limitations, including the fact that only data on serum potassium before and after dialysis were analyzed. Future studies should combine these data with data on dialysis duration, blood potassium changes during dialysis, residual renal function, and combined medication. The application of individualized $\mathrm{K}_{\mathrm{D}}$ dialysate also requires long-term assessments involving large samples. Ideally individualized dialysate should also include individualized other electrolytes such as sodium, calcium, magnesium and bicarbonate. There are even electrolyte devices that monitor in real time during dialysis, automatically adjusting dialysate concentration based on the target post-dialysis electrolyte concentration. Further research in engineering and clinical medicine is needed.

\section{Acknowledgments}

We acknowledge the National Natural Science Foundation of China. Thanks to all participants involved in this study. The nephrology branch of the Shanghai Medical Association played a leading and coordinating role in this study. Thanks to Shandong Weigao Renal Medical Instruments Co., Ltd., China, for providing $\mathrm{K}_{\mathrm{D}} 2.5 \mathrm{mmol} / \mathrm{L}$ and $\mathrm{K}_{\mathrm{D}} 3.0 \mathrm{mmol} / \mathrm{L}$ dialysate.

Funding: This work was sponsored by the National Natural Science Foundation of China (No. 81774060) and the Shanghai Minhang District Medical Specialty Construction Project (2020MWTZB07).

\section{Footnote}

Reporting Checklist: The authors have completed the STROBE reporting checklist. Available at https://dx.doi. org/10.21037/apm-21-3030 
Data Sharing Statement: Available at https://dx.doi. org/10.21037/apm-21-3030

Conflicts of Interest: All authors have completed the ICMJE uniform disclosure form (available at https://dx.doi. org/10.21037/apm-21-3030). All authors report Shandong Weigao Renal Medical Instruments Co., Ltd., China, provided $\mathrm{K}_{\mathrm{D}} 2.5 \mathrm{mmol} / \mathrm{L}$ and $\mathrm{K}_{\mathrm{D}} 3.0 \mathrm{mmol} / \mathrm{L}$ dialysate. The authors have no other conflicts of interest to declare.

Ethical Statement: The authors are accountable for all aspects of the work in ensuring that questions related to the accuracy or integrity of any part of the work are appropriately investigated and resolved. All procedures performed in this study involving human participants were in accordance with the Declaration of Helsinki (as revised in 2013). The study was approved by institutional ethics board of Fudan University Minhang Hospital (No.: 2020-038$01 \mathrm{~K}$ ), and informed consent was taken from all the patients.

Open Access Statement: This is an Open Access article distributed in accordance with the Creative Commons Attribution-NonCommercial-NoDerivs 4.0 International License (CC BY-NC-ND 4.0), which permits the noncommercial replication and distribution of the article with the strict proviso that no changes or edits are made and the original work is properly cited (including links to both the formal publication through the relevant DOI and the license). See: https://creativecommons.org/licenses/by-nc-nd/4.0/.

\section{References}

1. Shamseddin MK, Parfrey PS. Sudden cardiac death in chronic kidney disease: epidemiology and prevention. Nat Rev Nephrol 2011;7:145-54.

2. Makar MS, Pun PH. Sudden Cardiac Death Among Hemodialysis Patients. Am J Kidney Dis 2017;69:684-95.

3. Xu Q, Li H, Zhang X, et al. Tanshinone IIA elevates serum soluble klotho levels and de-creases cardiovascular events in patients on maintenance hemodialysis: a prospective before-after study. Ann Palliat Med 2020;9:2131-40.

4. Genovesi S, Valsecchi MG, Rossi E, et al. Sudden death and associated factors in a historical cohort of chronic haemodialysis patients. Nephrol Dial Transplant 2009;24:2529-36.

5. Jadoul M, Thumma J, Fuller DS, et al. Modifiable practices associated with sudden death among hemodialysis patients in the Dialysis Outcomes and Practice Patterns
Study. Clin J Am Soc Nephrol 2012;7:765-74.

6. Pani A, Floris M, Rosner MH, et al. Hyperkalemia in hemodialysis patients. Semin Dial 2014;27:571-6.

7. Yusuf AA, Hu Y, Singh B, et al. Serum Potassium Levels and Mortality in Hemodialysis Patients: A Retrospective Cohort Study. Am J Nephrol 2016;44:179-86.

8. Brunelli SM, Du Mond C, Oestreicher N, et al. Serum Potassium and Short-term Clinical Outcomes Among Hemodialysis Patients: Impact of the Long Interdialytic Interval. Am J Kidney Dis 2017;70:21-9.

9. Rhee CM, Chou JA, Kalantar-Zadeh K. Dialysis Prescription and Sudden Death. Semin Nephrol 2018;38:570-81.

10. Hung AM, Hakim RM. Dialysate and serum potassium in hemodialysis. Am J Kidney Dis 2015;66:125-32.

11. Charytan DM, Foley R, McCullough PA, et al. Arrhythmia and Sudden Death in Hemodialysis Patients: Protocol and Baseline Characteristics of the Monitoring in Dialysis Study. Clin J Am Soc Nephrol 2016;11:721-34.

12. Cupisti A, Galetta F, Morelli E, et al. Effect of hemodialysis on the dispersion of the QTc interval. Nephron 1998;78:429-32.

13. Wanner C, Herzog CA, Turakhia MP, et al. Chronic kidney disease and arrhythmias: highlights from a Kidney Disease: Improving Global Outcomes (KDIGO) Controversies Conference. Kidney Int 2018;94:231-4.

14. Sacher F, Jesel L, Borni-Duval C, et al. Cardiac Rhythm Disturbances in Hemodialysis Patients: Early Detection Using an Implantable Loop Recorder and Correlation With Biological and Dialysis Parameters. JACC Clin Electrophysiol 2018;4:397-408.

15. Lee S, Kang E, Yoo KD, et al. Lower serum potassium associated with increased mortality in dialysis patients: A nationwide prospective observational cohort study in Korea. PLoS One 2017;12:e0171842.

16. Ohnishi T, Kimachi M, Fukuma S, et al. Postdialysis Hypokalemia and All-Cause Mortality in Patients Undergoing Maintenance Hemodialysis. Clin J Am Soc Nephrol 2019;14:873-81.

17. Agar BU, Culleton BF, Fluck R, et al. Potassium kinetics during hemodialysis. Hemodial Int 2015;19:23-32.

18. Lee J, Mendelssohn DC. Optimizing dialysate potassium. Hemodial Int 2016;20:573-9.

19. Silva BC, Moyses RM, Elias RM. Dialysate and Serum Potassium in Hemodialysis. Am J Kidney Dis 2016;67:165.

20. Pun PH. Dialysate potassium concentration: Should mass balance trump electrophysiology? Semin Dial 2018;31:569-75. 
21. Pun PH, Lehrich RW, Honeycutt EF, et al. Modifiable risk factors associated with sudden cardiac arrest within hemodialysis clinics. Kidney Int 2011;79:218-27.

22. Weisberg LS, Rachoin JS. The safety of low-potassium dialysis. Semin Dial 2010;23:556-60.

23. Hoppe LK, Muhlack DC, Koenig W, et al. Association of Abnormal Serum Potassium Levels with Arrhythmias and Cardiovascular Mortality: a Systematic Review and MetaAnalysis of Observational Studies. Cardiovasc Drugs Ther 2018;32:197-212.

24. Kovesdy CP, Regidor DL, Mehrotra R, et al. Serum and dialysate potassium concentrations and survival in hemodialysis patients. Clin J Am Soc Nephrol 2007;2:9991007.

25. Karaboyas A, Zee J, Brunelli SM, et al. Dialysate Potassium, Serum Potassium, Mortality, and Arrhythmia Events in Hemodialysis: Results From the Dialysis Outcomes and Practice Patterns Study (DOPPS). Am J Kidney Dis 2017;69:266-77.

26. Dolson GM, Ellis KJ, Bernardo MV, et al. Acute decreases in serum potassium augment blood pressure. Am J Kidney Dis 1995;26:321-6.

27. Moledina D, Geller D. Is low dialysate potassium ever indicated in outpatient hemodialysis? Semin Dial 2014;27:263-5.

28. Ferrey A, You AS, Kovesdy CP, et al. Dialysate Potassium and Mortality in a Prospective Hemodialysis Cohort. Am J Nephrol 2018;47:415-23.

29. Bleyer AJ, Hartman J, Brannon PC, et al. Characteristics of sudden death in hemodialysis patients. Kidney Int 2006;69:2268-73.

30. Labriola L, Jadoul M. Sailing between Scylla and Charybdis: the high serum K-low dialysate K quandary.

Cite this article as: $\mathrm{He} \mathrm{H}, \mathrm{Wu} \mathrm{J}, \mathrm{Lu} \mathrm{W}, \mathrm{Wu} \mathrm{H}, \mathrm{Zhu} R$, Yu G, Jiang G, Wang N, Guo Z, Deng Y, Xu X. A multicenter study of hemodialysis using individualized dialysate potassium concentrations. Ann Palliat Med 2021;10(12):12218-12229. doi: 10.21037/apm-21-3030
Semin Dial 2014;27:463-71.

31. Brunelli SM, Spiegel DM, Du Mond C, et al. Serum-todialysate potassium gradient and its association with shortterm outcomes in hemodialysis patients. Nephrol Dial Transplant 2018;33:1207-14.

32. Tucker B, Moledina DG. We Use Dialysate Potassium Levels That Are Too Low in Hemodialysis. Semin Dial 2016;29:300-2.

33. Huang CW, Lee MJ, Lee PT, et al. Low Potassium Dialysate as a Protective Factor of Sudden Cardiac Death in Hemodialysis Patients with Hyperkalemia. PLoS One 2015;10:e0139886.

34. Blumberg A, Roser HW, Zehnder C, et al. Plasma potassium in patients with terminal renal failure during and after haemodialysis; relationship with dialytic potassium removal and total body potassium. Nephrol Dial Transplant 1997;12:1629-34.

35. Nakhoul GN, Huang H, Arrigain S, et al. Serum Potassium, End-Stage Renal Disease and Mortality in Chronic Kidney Disease. Am J Nephrol 2015;41:456-63.

36. Weinberg JM, Appel LJ, Bakris G, et al. Risk of hyperkalemia in nondiabetic patients with chronic kidney disease receiving antihypertensive therapy. Arch Intern Med 2009;169:1587-94.

37. Sarafidis PA, Blacklock R, Wood E, et al. Prevalence and factors associated with hyperkalemia in predialysis patients followed in a low-clearance clinic. Clin J Am Soc Nephrol 2012;7:1234-41.

38. Gilligan S, Raphael KL. Hyperkalemia and Hypokalemia in CKD: Prevalence, Risk Factors, and Clinical Outcomes. Adv Chronic Kidney Dis 2017;24:315-8.

(English Language Editor: B. Meiser) 